Published by Al-Nahrain College of Medicine P-ISSN 1681-6579

E-ISSN 2224-4719

Email: iraqijms@colmed-alnahrain.edu.iq

http://www.colmed-alnahrain.edu.iq

http://www.iraqijms.net

Iraqi JMS 2018; Vol. 16(4)

\title{
Extraction, Purification and Therapeutic Use of Bacteriophage Endolysin against Multi-Drug Resistant Pseudomonas aeruginosa: An In-vitro and In-vivo Study
}

\author{
Mohammed R. Ali ${ }^{1} P h D$, Shurooq R. Kadhim ${ }^{2} P h D$, Ahmed S. Abdulamir ${ }^{1} P h D$ \\ ${ }^{1}$ Dep.t of Microbiology, College of Medicine, Al-Nahrain University, Baghdad, Iraq, ${ }^{2}$ Dept. of Microbiology, College of \\ Pharmacy, Al-Mustansiriya University, Baghdad, Iraq
}

\begin{abstract}
Background Persistent infection with multidrug resistant Pseudomonas aeruginosa ( $P$. aeruginosa) represents a real problem for health care providers. Bacteriophage lytic enzymes or lysins are highly evolved molecules that have been specifically developed by phages to quickly and efficiently allow their progeny to be released from the host bacterium while destructing that bacterium.

Objective Isolation of endolysin from P. aeruginosa bacteriophages, and administering them systematically in vivo lab animal and measuring their therapeutic efficacy as well as evaluation of their biosafety.

Methods This study was performed from March 2015 - August 2017, during which 50 bacteriological samples of $P$. aeruginosa were collected, and examined for their antibiogram, then bacteriophage cocktails were done for 5 resistant strains of them. Endolysins were extracted from their corresponding bacteriophages and characterized. The enzymatic and antibacterial activities as well in vivo therapeutic efficiency of these enzymes were investigated.

Results This study showed that the extracted endolysin from these bacteriophages was effective in treating laboratory mice from bacteremia with $P$. aeruginosa and saving their lives when injected intraperitoneal.

Conclusion Endolysin can be extracted directly from their bacteriophages and used effectively in proper doses to treat bacteremia in mice.

Keywords Pseudomonas aeruginosa, bacteriophage, endolysin, MDR

Citation Ali MR, Kadhim SR, Abdulamir AS. Extraction, purification and therapeutic use of bacteriophage endolysin against multi-drug resistant Pseudomonas aeruginosa: An in-vitro and in-vivo study. Iraqi JMS. 2018; 16(4): 405-412. doi: 10.22578/IJMS.16.4.8
\end{abstract}

List of abbreviations: EDTA = Ethylenediaminetetra acetic acid, $L B=$ Luria-Bertani broth, $M D R=$ Multi-drug resistant, $O D=$ Optical density, $\mathrm{P}=$ Pseudomonas, $\mathrm{PBS}=$ Phosphate buffer saline, $\mathrm{pP}=$ Phage to Pseudomonas aeruginosa

\section{Introduction}

$\mathrm{B}$ acterial infections are responsible for significant morbidity and mortality in clinical settings ${ }^{(1)}$. Many infections that would have been cured easily by antibiotics in the past now are resistant, resulting in sicker patients and longer hospitalizations. The endolysins of the bacteriophages are highly evolved molecules that have been specifically developed by phages to quickly and efficiently allow their progeny to be released from the host bacterium. These enzymes damage the bacterial cell wall's integrity by hydrolyzing the four major bonds in its peptidoglycan component (2). The endolysins that have been characterized are amidases; usually do not have signal sequences to translocate them 
through the cytoplasmic membrane and cleave their substrate in the peptidoglycan. Instead, the endolysins' translocation is controlled by a second phage gene products called holins (3). During the bacteriophages development in the infected bacterium, endolysin accumulates in the cytoplasm until bacteriophage maturation. During a specific time genetically controlled, holin molecules, which inserted in the cytoplasmic membrane are activated, resulting in the formation of pores so the preformed endolysin in the cytoplasm can access the peptidoglycan, there-by causing cell lysis and the release of the new bacteriophages (4). Bacteriophages are able to lyse their targeted bacterial hosts, a fact that has been known for almost a century, and since the late 1910s bacteriophages have been used to prevent and treat human and animal diseases of bacterial origin. However, bacteriophage-encoded enzymes have only newly begun to be used for various applications; e.g.: reducing bacterial contamination in dairy products and the preparation of bacterial vaccines ${ }^{(5,6)}$.

The current study aimed to isolate endolysin from $P$. aeruginosa bacteriophages, and evaluate their therapeutic efficacy as well as their biosafety in lab animals.

\section{Methods}

Samples of bacteria were collected from AlImamein Al-Kadhimein Medical City. A total of 50 different $P$. aeruginosa isolates were collected from Bacteriology laboratory. The specimens were collected from hospitalized patients and outpatients suffering from severe urinary tract infection, otitis media, skin infection, and septicemia. The specimens were cultured in screw universal tubes containing nutrient broth wrapped by parafilm or by using sterile swabs; both were put in ice bags and were transferred at the same day to the laboratory of Microbiology Department in the College of Medicine, Al-Nahrain University to be subcultured on nutrient agar or stored in refrigerator at $40 \mathrm{C}$ for $24 \mathrm{~h}{ }^{(7)}$.

Different crude samples for phage isolation were obtained from different regions in
Baghdad including sewage $(30-40 \mathrm{ml})$, waste water $(30-40 \mathrm{ml})$, feces of sheep $(20 \mathrm{gm})$, chicken litter (15-20 gm), swab from surgical lounges during the period from January 2015 to June 2015. The samples were put in clean test tubes wrapped by parafilm in ice bag and transported to the laboratory in the same day. Each sample was divided into two aliquots; one was stored in the refrigerator at $40{ }^{\circ} \mathrm{C}$ until be used and the other was worked at the same day.

Stored specimens were plated on nutrient agar by streaking method. $P$. aeruginosa formed smooth round colonies with a fluorescent greenish color on nutrient agar. Single colonies of $P$. aeruginosa from a growing stock were recultured by $A B C$ streaking on nutrient agar plates in order to isolate single discrete colonies. Then, a battery of diagnostic approaches was pursued for the diagnosis of Pseudomonas bacteria including oxidase test, Gram staining, microscopical examination and Luria broth. This media was prepared according to the manufacturing instructions and sterilized by autoclaving at $121{ }^{\circ} \mathrm{C}$ for $15 \mathrm{~min}$. Diagnosis of the isolated bacteria relied first on oxidase test. Oxidase positive isolates suggests Pseudomonas species, microscopic examination (rod shaped bacteria), Gram staining (Gram-negative rods) confirm the presence of $P$. aeruginosa. The bacteria were stocked in Luria-Bertani broth containing glycerol $(30 \% \mathrm{v} / \mathrm{v})$ and preserved at $-20^{\circ} \mathrm{C}$.

Primary phages are those phages that were isolated from environmental specimens when were mixed with target bacteria. The procedure of isolating and propagating primary phages was done according to the methodology conducted in a patent concerned with phage isolation ${ }^{(8)}$.

Virulent phages were screened by phage spotting test on a nutrient-agar. Phage spotting can be used to provide a first approximation of the ability of a phage to lyse certain bacterial isolates. The formation of clear zones suggests the presence of lytic phages ${ }^{(9)}$.

The therapeutic effect of extracted endolysin was evaluated by using three groups of mice ( 2 months' age, weighed $25 \pm 1.5 \mathrm{~g} /$ mice) for each 
bacterium ( $P$. aeruginosa), each group was composed of 5 mice.

The first two groups of mice received intraperitoneal (IP) injections of $400 \mu$ l aliquots of bacterial suspension at concentration 108 $\mathrm{CFU} / \mathrm{ml}$, one of these groups was treated with $0.4 \mathrm{ml}$ of $20 \mu \mathrm{g} / \mathrm{ml}$ of Pseudomonas specific endolysin, which was injected $3 \mathrm{~h}$ after the bacterial challenge in order to evaluate the ability of administered endolysin to rescue the tested bacteremic mice from the inevitable fate of death by the bacterial infection (9). On the other hand, the third group received only
IP injection with $0.4 \mathrm{ml}$ of $20 \mu \mathrm{g} / \mathrm{ml}$ of Pseudomonas specific endolysin without bacterial infection.

After disinfecting the area of injection by $70 \%$ alcohol, the first and second groups of mice were injected IP with $108 \mathrm{CFU} / \mathrm{ml}$ of the bacterial isolate. Then, every hour interval, the mice of control, test, and endolysin only groups were monitored for their health and physical activities and timely health score was recorded. According to (Biswas) ${ }^{(10)}$, certain health scoring system was used as shown in table (1).

Table 1. The health scoring system of bacteremic mice

\begin{tabular}{cc}
\hline Health signs & Health level \\
\hline Normal and unremarkable condition & 5 \\
Slight illness(lethargy and ruffled fur) & 4 \\
Moderate illness(severe lethargy, ruffled fur, and hunched back) & 3 \\
Sever illness (severe lethargy, ruffled fur, hunched back, and exudative & 2 \\
accumulation around partially closed eyes) \\
Moribund state \\
Death & 1 \\
\hline
\end{tabular}

\section{Results}

In this study, three phages active against $P$. aeruginosa were isolated and purified. All of the isolated phages formed visible plaques in the early stage when tested on bacterial lawn of specific MDRs P. aeruginosa. They were isolated directly from environment by showing lysis on bacterial lawns as shown in figure (1).

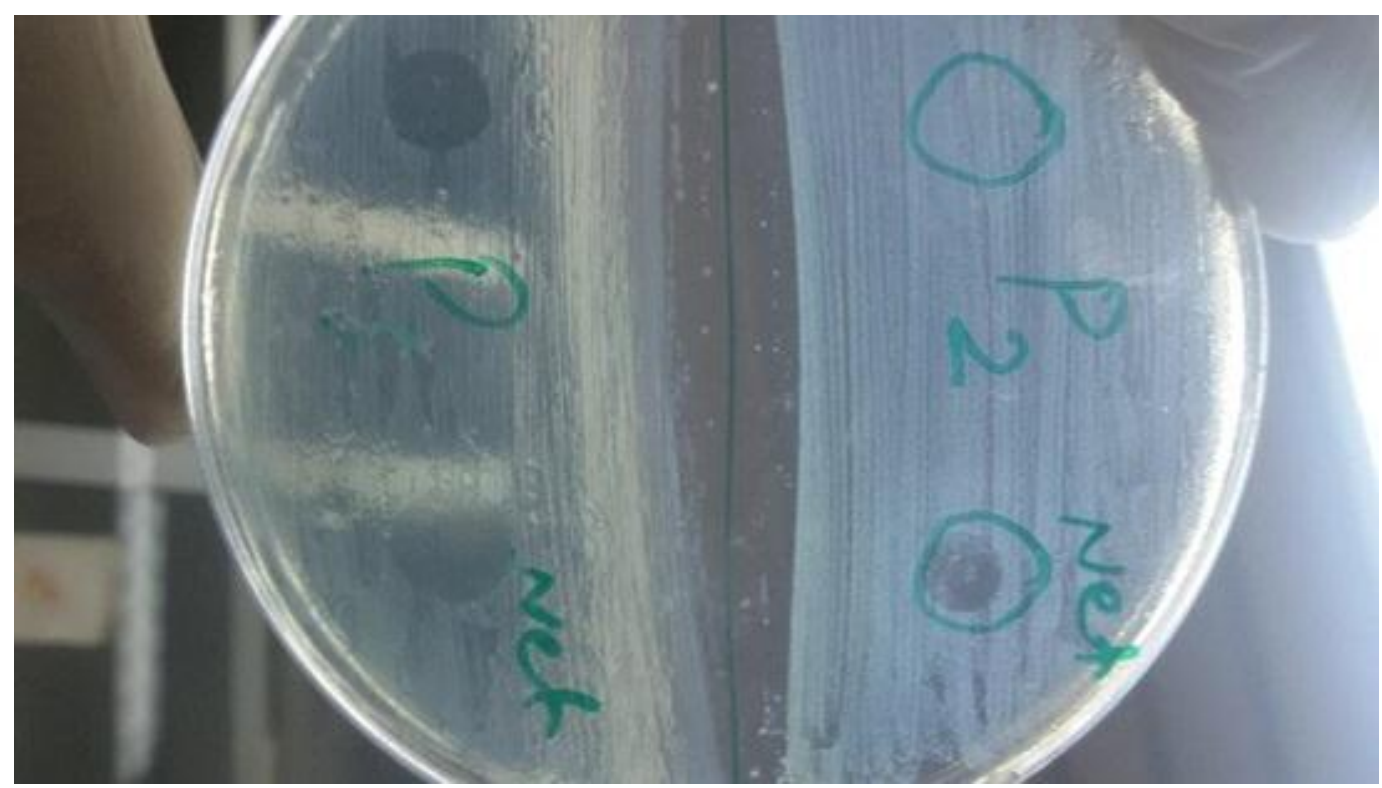

Figure 1. Phage spot assay of bacteriophage to Pseudomonas aeruginosa 
Characteristics of these phages were determined by the diameter, clarity/turbidity, margin cut, and shape of their plaques. The size of plaques ranged between $1.5-2.6 \mathrm{~mm}$. The morphological characteristics of the plaques are shown in table (2).

Table 2. The plaque characteristics of the isolated phages to MDR Pseudomonas aeruginosa bacteria

\begin{tabular}{ccccc}
\hline $\begin{array}{c}\text { Bacteriophage } \\
\text { isolates }\end{array}$ & $\begin{array}{c}\text { Plaques Size } \\
(\mathbf{m m})\end{array}$ & Margin cut & $\begin{array}{c}\text { Plaques } \\
\text { clarity }\end{array}$ & $\begin{array}{c}\text { Plaques } \\
\text { shape }\end{array}$ \\
\hline pP1 & 1.5 & Irregular & Clear & Circular \\
pP2 & 2.6 & Irregular & Semi-clear & Oval \\
pP3 & 1.8 & Irregular & Semi-clear & Circular \\
\hline
\end{tabular}

pP: phage to Pseudomonas aeruginosa

Endolysin was successfully extracted from all the three $P$. aeruginosa bacteriophages using sephadex G100 column chromatography. After sephadex G100 chromatography, each bacteriophage lysate gave eight aliquots of 0.5 $\mathrm{ml}$ eluted fluid fractions in Eppendrof tubes, one of them showed positive result on corresponding bacterial lawns as shown in table (3).

Table 3. The fraction that endolysin like activity was found for each bacteriophage

\begin{tabular}{cc}
\hline Bacteriophage & Endolysin positive tube \\
\hline PP1 & $2^{\text {nd }}$ \\
PP2 & $3^{\text {rd }}$ \\
pP3 & $2^{\text {nd }}$ \\
\hline
\end{tabular}

pP: phage to Pseudomonas aeruginosa

The optical density of bacterial broth for each bacteria was measured initially once at zero time, just before the addition of corresponding endolysin. After the addition of the purified endolysin, three days after their extraction, with the concentrations $(25,40,20 \mu \mathrm{g} / \mathrm{ml})$, the optical density was measured every five minutes till one hour. The optical density of the tested bacterial broth was obviously decreasing with time as shown in table ( $4 \mathrm{a}$ and $\mathrm{b}$ ).

The result of this experiment showed that the health score of the first group (five mice injected with bacteria alone) started to decrease after two hours, afterwards the health score declined progressively. They died after eight hours. On the other hand, the second group (five mice injected with bacteria and endolysin) lived for more than four weeks with full physical activity and the third group (five mice injected with endolysin alone) also lived for more than four weeks with full physical activity.as shown in tables (5) and (6). 
Table 4a. Changes of optical density of bacterial broth with endolysin addition

\begin{tabular}{cccc}
\hline Time (min.) & OD of P1* & OD of P2 & OD of P3 \\
\hline $\mathbf{0}$ & 1.34 & 1.34 & 1.34 \\
$\mathbf{5}$ & 1.3 & 1.32 & 1.29 \\
$\mathbf{1 0}$ & 1.25 & 1.27 & 1.24 \\
$\mathbf{1 5}$ & 1.21 & 1.24 & 1.16 \\
$\mathbf{2 0}$ & 1.12 & 1.19 & 1.09 \\
$\mathbf{2 5}$ & 1.05 & 1.14 & 1.02 \\
$\mathbf{3 0}$ & 0.96 & 1.07 & 0.94 \\
$\mathbf{3 5}$ & 0.85 & 0.98 & 0.85 \\
$\mathbf{4 0}$ & 0.76 & 0.92 & 0.74 \\
$\mathbf{4 5}$ & 0.64 & 0.83 & 0.63 \\
$\mathbf{5 0}$ & 0.56 & 0.74 & 0.5 \\
$\mathbf{5 5}$ & 0.52 & 0.65 & 0.46 \\
$\mathbf{6 0}$ & 0.49 & 0.56 & 0.43 \\
\hline $\mathbf{\Delta}$ OD/ $\mathbf{m i n}$ & 0.014 & 0.013 & 0.015 \\
\hline
\end{tabular}

*: net OD of P1-3 after deducting OD of the broth only (0.46)

OD: optical density, P: Pseudomonas aeruginosa

Table 4b. Pace of OD change every 5 minutes

\begin{tabular}{cccc}
\hline Time (min.) & $\boldsymbol{\Delta}$ OD of P1 & $\boldsymbol{\Delta}$ OD of P2 & $\boldsymbol{\Delta}$ OD of P3 \\
\hline 5 & 0.04 & 0.02 & 0.05 \\
10 & 0.05 & 0.05 & 0.05 \\
15 & 0.04 & 0.03 & 0.08 \\
20 & 0.09 & 0.05 & 0.07 \\
25 & 0.07 & 0.05 & 0.07 \\
30 & 0.09 & 0.07 & 0.08 \\
35 & 0.11 & 0.09 & 0.09 \\
40 & 0.09 & 0.06 & 0.11 \\
45 & 0.12 & 0.09 & 0.11 \\
50 & 0.08 & 0.09 & 0.13 \\
55 & 0.04 & 0.09 & 0.04 \\
60 & 0.03 & 0.09 & 0.03 \\
\hline
\end{tabular}


Table 5. Health score of mice injected with bacteria alone or with endolysin

\begin{tabular}{cccccc}
\hline Hours & $\begin{array}{c}\text { Health scores } \\
\text { bacteremic } \\
\text { group 1 }\end{array}$ & $\begin{array}{c}\text { Median of } \\
\text { health } \\
\text { scores of } \\
\text { bacteremic } \\
\text { group 1 }\end{array}$ & $\begin{array}{c}\text { Health } \\
\text { scores of } \\
\text { test group 2 } \\
\text { (bacteria + } \\
\text { endolysin) }\end{array}$ & $\begin{array}{c}\text { Median of health } \\
\text { scores of test } \\
\text { group 2 } \\
\text { (bacteria + } \\
\text { endolysin) }\end{array}$ & $\begin{array}{c}\text { P value } \\
\text { (Mann } \\
\text { Whitney } \\
\text { test) }\end{array}$ \\
\hline 0 h & $5,5,5,5,5$ & 5 & $5,5,5,5,5$ & 5 & 0.920 \\
$2 \mathrm{~h}$ & $3,3,4,3,2$ & 3 & $3,4,3,3,4$ & 3 & 0.465 \\
$4 \mathrm{~h}$ & $3,2,3,3,1$ & 3 & $5,5,4,4,5$ & 5 & 0.012 \\
$6 \mathrm{~h}$ & $1,1,1,1,0$ & 1 & $5,5,5,5,5$ & 5 & 0.012 \\
$8 \mathrm{~h}$ & $0,0,0,0,0$ & 0 & $5,5,5,5,5$ & 5 & 0.012 \\
\hline
\end{tabular}

Table 6. Health Score of mice Injected with endolysin alone or nothing

\begin{tabular}{cccccc}
\hline Hours & $\begin{array}{c}\text { Health scores } \\
\text { endolysin only } \\
\text { group 3 }\end{array}$ & $\begin{array}{c}\text { Median of health } \\
\text { scores of } \\
\text { endolysin only } \\
\text { group 3 }\end{array}$ & $\begin{array}{c}\text { Health } \\
\text { scores of } \\
\text { healthy } \\
\text { group 4 }\end{array}$ & $\begin{array}{c}\text { Median of health } \\
\text { scores of healthy } \\
\text { group 4 }\end{array}$ & $\begin{array}{c}\text { P value } \\
\text { (Mann } \\
\text { Whitney } \\
\text { test) }\end{array}$ \\
\hline O h & $5,5,5,5,5$ & 5 & $5,5,5,5,5$ & 5 & 0.920 \\
$2 \mathrm{~h}$ & $5,5,5,5,5$ & 5 & $5,5,5,4,5$ & 5 & 0.674 \\
$4 \mathrm{~h}$ & $5,5,5,5,5$ & 5 & $5,5,4,4,5$ & 5 & 0.347 \\
$6 \mathrm{~h}$ & $5,5,5,5,5$ & 5 & $5,5,5,5,5$ & 5 & 0.920 \\
$8 \mathrm{~h}$ & $5,5,5,5,5$ & 5 & $5,5,5,5,5$ & 5 & 0.920 \\
\hline
\end{tabular}

\section{Discussion}

Phage lysin therapy is a possible alternative to antibiotics for the treatment of bacterial infections. Indeed, it has proven to be medically superior to antibiotic therapy ${ }^{(12,13)}$. The results of the current research support this notion, as phage lysin was shown to be highly efficacious against infections caused by inoculation with antibiotic-resistant $P$. aeruginosa.

In this study, three phages for different $P$. aeruginosa were isolated and characterized. The phages demonstrated high lytic activity underscoring its great potential to treat infections with these bacteria. The experiments presented here revealed that a single intraperitoneal injection of the corresponding lysin rescued mice from death due to $P$. aeruginosa even when bacteremia was already well established, and it was observed that effective protection was achieved in mice when a single dose of a specific endolysin was administered two hours after inoculation of $P$. aeruginosa.

The results obtained in this experiments are encouraging, since these findings and those of others support the development in a near future of modified procedures to improve the use of lysins in a more efficient way. For example, intravenous administration of the enzymes may confer a superior protection to animals when used later after the challenge. Most interestingly, a single intraperitoneal injection of endolysin was sufficient for a complete cure of mice. provides a rapid and specific lytic activity, making these proteins very promising candidates in current antimicrobial therapies ${ }^{(14)}$.

This study shows that bacteriophage lysins from $P$. aeruginosa can be used to efficiently reduce the bacterial burden of these bacteria, which are multidrug resistant, both in vitro and 
in vivo, and this study emphasizes the potential therapeutic role of phage lysins for treatment of Gram-negative bacterial infections.

Animal studies have generally supported the utility and safety of endolysin phage therapy against bacterial pathogens, such as $P$. aeruginosa ${ }^{(15)}$.

The route of endolysin phage administration was particularly important to the efficacy of the treatment. Intraperitoneal route provides significant protection similar to that of intravenous route. It was stated that endolysin for $P$. aeruginosa phages administered by the IP route are distributed, in high titers, more rapidly and delivered for a more sustained period of time to all of the tissues (15).

Actually using a severe model of sepsis that leads to $100 \%$ lethality of mice in less than $24 \mathrm{~h}$ is a difficult challenge for every imaginable antibacterial agent. Two hours after bacterial injection, health score of mice began to decline progressively; A single injection of endolysin, rescued $100 \%$ of MDR $P$. aeruginosa septicemic mice. Thus, this study showed that endolysin administered in a single dose $2 \mathrm{~h}$ post bacterial infection resulted in $100 \%$ survival of treated mice when compared to the control group.

This study concluded that endolysin can be extracted directly from their bacteriophages and used by injection of mice with bacteremia with the proper dose of the extracted endolysin of the corresponding bacteriophages which was effective in all of them.

\section{Acknowledgments}

Special thanks for the staff members of Microbiology Department, College of Medicine, Al-Nahrain University for their continuous support, and the Research Unit staff in the College of Medicine, Al-Nahrain University for help in extraction, purification and characterization of the endolysins of the corresponding bacteriophages.

\section{Author Contribution}

Dr. Abdulamir: made the research design and the protocol for bacteriophages formulation. Dr. Kadhim helped in research design with extraction of the endolysin. Dr. Ali collected the bacterial and bacteriophage samples with their preparation and isolation and the endolysin extraction with its characterization, and he reviewed and wrote this article.

\section{Conflict of interest}

No conflicts of interest.

Funding

Self-funding.

\section{References}

1. Wise R. The relentless rise of resistance. J Antimicrob Chemother. 2004; 54(2): 306-10. doi: 10.1093/jac/dkh340.

2. Young R. Bacteriophage lysis: mechanism and regulation. Microbiol Rev. 1992; 56(3): 430-81.

3. Wang IN, Smith DL, Young R. The protein clocks of bacteriophage infections. Annu Rev Microbiol. 2000; 54: 799-825. doi: 10.1146/annurev.micro.54.1.799.

4. Szostak MP, Hensel A, Eko FO, et al. Bacterial ghosts: non-living candidate vaccines. J Biotechnol. 1996; 44(1-3): 161-70. doi: 10.1016/0168-1656(95)00123-9.

5. Gaeng $S$, Scherer $S$, Neve $H$, et al. Gene cloning and expression and secretion of Listeria monocytogenes bacteriophage-lytic enzymes in Lactococcus lactis. Appl Environ Microbiol. 2000; 66(7): 2951-8.

6. Bauer AW, Kirby WM, Sherris JC, et al. Antibiotic susceptibility testing by a standardized single disc method. Am J Clin Pathol. 1966; 45(4): 493-6.

7. Budzik JM, Rosche WA, Rietsch A, et al. Isolation and P. aeruginosa CRISPR/Cas and Bacteriophage Resistance a generalized transducing phage for Pseudomonas aeruginosa strains PAO1 and PA14. J Bacteriol. 2004; 186: 3270-3. doi: 10.1128/JB.186.10.3270-3273.2004

8. Jassim SA, Abdualamir AS, Abu baker F. Methods for bacteriophage design in "international application published under the patent cooperation (PCT)" (W.I.P. organization, ed.), 2010. Vol.WO2010064044 A1.

9. Hall-Stoodley L, Costerton JW, Stoodley P. Bacterial biofilms: From the natural environment to infectious diseases. Nat Rev Microbiol. 2004; 2(2): 95-108. DOI: 10.1038/nrmicro821.

10. Biswas B, Adhya $S$, Washart $P$, et al. Bacteriophage therapy rescues mice bacteremic from a clinical isolate of vancomycin-resistant Enterococcus faecium. Infect Immun. 2002; 70(1): 204-10.

11. Donovan D. M. Bacteriophage and peptidoglycan degrading enzymes with antimicrobial applications. Recent Pat Biotechnol. 2007; 1(2): 113-22.

12. Gu J, Xu W, Lei L, et al. LysGH15, a novel bacteriophage lysin, protects a murine bacteremia model efficiently against lethal methicillin-resistant Staphylococcus aureus infection. J Clin Microbiol. 2011 Jan;49(1):111-7. doi: 10.1128/JCM.01144-10. 
13. Schuch R, Nelson D, Fischetti VA. A bacteriolytic agent that detects and kills Bacillus anthracis. Nature. 2002; 418(6900): 884-9. DOI: 10.1038/nature01026

14. McVay CS, Velásquez M, Fralick JA. Phage therapy of Pseudomonas aeruginosa infection in a mouse burn wound model. Antimicrob Agents Chemother. 2007; 51(6): 1934-8. doi: 10.1128/AAC.01028-06

15. Soothill JS. Bacteriophage prevents destruction of skin grafts by Pseudomonas aeruginosa. Burns. 1994; 20(3): 209-11.
Correspondence to Dr. Mohammed R. Ali

E-mail: dr_mohamadrazak@colmedalnahrain.edu.iq

dr_mohamadrazak@yahoo.com

Received Feb. $1^{\text {st }} 2018$

Accepted Apr. $5^{\text {th }} 2018$ 